\title{
Introduction to the special section bio-optical and biogeochemical conditions in the South East Pacific in late 2004: the BIOSOPE program
}

\author{
H. Claustre ${ }^{1,2}$, A. Sciandra ${ }^{1,2}$, and D. Vaulot ${ }^{3}$ \\ ${ }^{1}$ CNRS, UMR 7093, Laboratoire d'océanographie de Villefranche, 06230 Villefranche-sur-Mer, France \\ ${ }^{2}$ Université Pierre et Marie Curie-Paris 6, UMR 7093, Laboratoire d'océanographie de Villefranche, 06230 \\ Villefranche-sur-Mer, France \\ ${ }^{3}$ Station Biologique de Roscoff, UMR 7144 CNRS et Université Pierre et Marie Curie, BP 74, 29682 Roscoff Cx, France
}

Received: 28 November 2007 - Published in Biogeosciences Discuss.: 12 February 2008

Revised: 17 April 2008 - Accepted: 18 April 2008 - Published: 6 May 2008

\begin{abstract}
The objectives of the BIOSOPE (BIogeochemistry and Optics SOuth Pacific Experiment) project was to study, during the austral summer, the biological, biogeochemical and bio-optical properties of different trophic regimes in the South East Pacific: the eutrophic zone associated with the upwelling regime off the Chilean coast, the mesotrophic area associated with the plume of the Marquises Islands in the HNLC (High Nutrient Low Chlorophyll) waters of this subequatorial area, and the extremely oligotrophic area associated with the central part of the South Pacific Gyre (SPG). At the end of 2004, a 55-day international cruise with 32 scientists on board took place between Tahiti and Chile, crossing the SPG along a North-West South-East transect. This paper describes in detail the objectives of the BIOSOPE project, the implementation plan of the cruise, the main hydrological entities encountered along the $\sim 8000 \mathrm{~km}$ South East Pacific transect, and ends with a general overview of the 32 other papers published in this special issue.
\end{abstract}

\section{Prior oceanographic knowledge of the South East Pa- cific}

The South East Pacific (SEP $5^{\circ} \mathrm{S}-40^{\circ} \mathrm{S}$, East of $150^{\circ} \mathrm{W}$ ) makes the connection between tropical and high latitudes of the austral ocean. It remains the most sparsely-sampled oceanic region of the global ocean from both hydrodynamic (Leth et al., 2004) and biogeochemical (Daneri and Quinones, 2001) points of view.

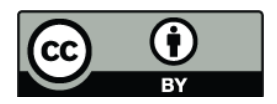

Correspondence to: H. Claustre (claustre@obs-vlfr.fr)
Large scale investigations have been initially conducted as part of the transpacific SCORPIO sections performed along $43^{\circ} \mathrm{S}$ and $28^{\circ} \mathrm{S}$ (Reid, 1973) and the Hawaii-to-Tahiti shuttle experiment (Wyrtki and Kilonsky, 1984), following the EASTROPAC cruises carried out in 1967-1968. More recently, these observations have been supplemented with some WOCE sections (P6 lines, e.g. Wijffels et al. 2001; P19 line Tsuchiya and Talley, 1998) and with the rather intensive deployment of drifters and profiling floats as part of the ARGO program. The general patterns of the surface circulation in the South Equatorial Pacific region can be characterized by three main current regimes (Chaigneau and Pizarro, 2005a; Kessler 2006). On its equator side, the South Pacific Gyre (SPG) is delineated by the South Equatorial Current (SEC) flowing westwards and sometimes embedding the (weaker) South Equatorial Counter Current (SECC) (Wyrtki and Kilonsky, 1984; Eldin, 1983). On its polar side, the (weak) South Pacific Current (SPC), corresponding to the eastern extension of the West Wind Drift, flowing eastward near $\sim 30^{\circ} \mathrm{S}$, forms the southern closure of the subtropical gyre circulation (Stramma et al., 1995). Approaching South America, this current turns northwards and contributes to the diffuse surface flows of the broad Peru-Chile (Humboldt) Current (PCC); it can reach punctual velocities of $15-20 \mathrm{~cm} \mathrm{~s}^{-1}$ (Chaigneau and Pizarro, 2005b) and sometimes presents complex motions near the coast, with important mesoscale activity (eddies and filaments) associated with the coastal upwelling regime (e.g. Shaffer et al., 1995). Below the PCC, the Peru Chile Undercurrent (PCUC), restricted to a narrow band near and above the shelf break, transports towards the pole the warm and salty subsurface equatorial waters (Silva and Neshyba, 1979).

Published by Copernicus Publications on behalf of the European Geosciences Union. 

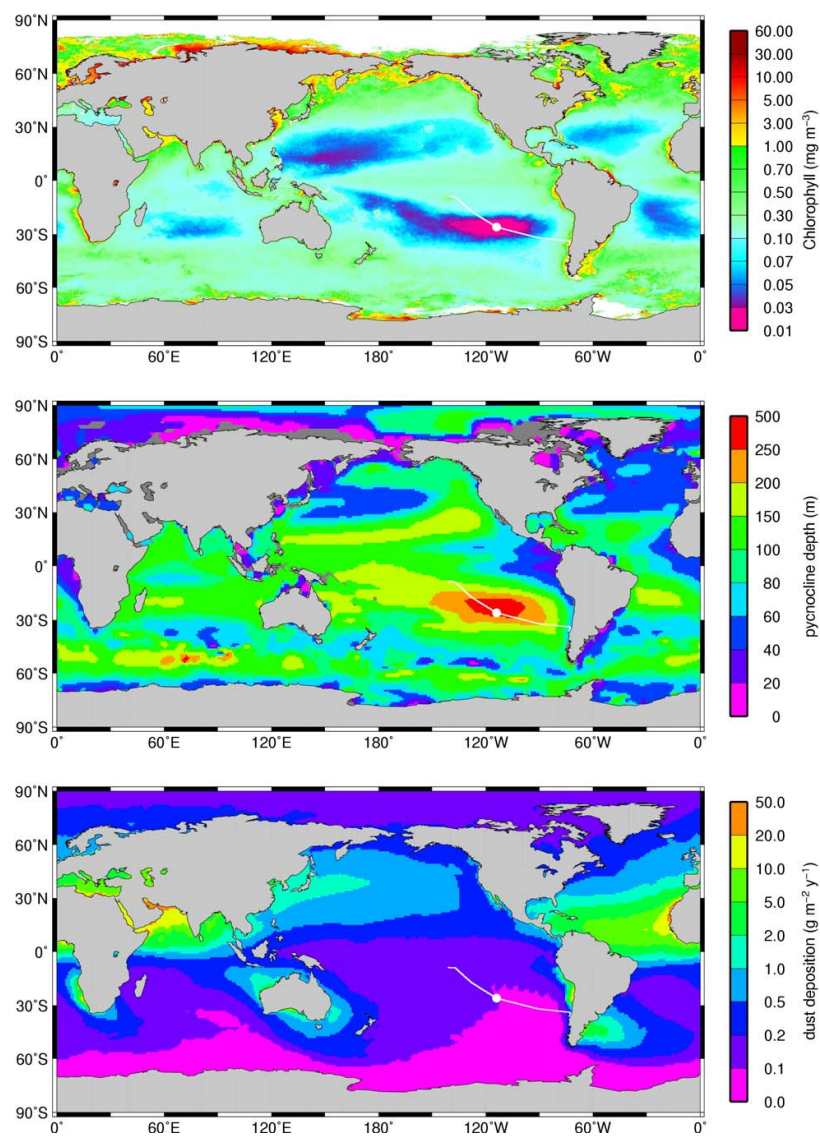

Fig. 1. Global context of the BIOSOPE cruise in the South East Pacific. (a) Annual composite image of SeaWiFS derived Chl- $a$ for year 2000. (b) Distribution of the pycnocline depth (adapted from Fiedler and Talley, 2006). (c) Dust deposition flux at the ocean surface (adapted from Mahowald et al., 2005). The white line identifies the cruise track of the BIOSOPE cruise. The white circle corresponds to the GYR station located in the core of the SPG and investigated over a 5-day period.

Even fewer investigations have been dedicated to asses the biological and biogeochemical status of the SEP. Yet, this area, as a result of the hydrodynamical forcing described above presents a remarkable diversity of trophic conditions and even some singularities that do not have any counterpart in others areas of the world ocean. Basically three main biogeochemical regimes can be identified in this large water mass.

The SPG is the largest subtropical anticyclonic gyre and the least described region of the ocean (Longhurst, 1998; Claustre and Maritorena, 2003). Indeed, to our knowledge, the few biological observation reported to date concerns phytoplankton production (Forgsbergh and Joseph 1963), some (very low) chlorophyll concentration along $105^{\circ} \mathrm{W}$ (Chavez et al., 1995), near surface phytoplankton determination along $110^{\circ} \mathrm{W}$ (Hardy et al., 1996) and a recent analysis on picophytoplankton distribution in the upper layer along $32^{\circ} \mathrm{S}$
(Bouman et al., 2006; Grob et al., 2006). Thanks to satellite remote sensing of ocean color, some general surface properties of the SPG have emerged. The SPG is the most oligotrophic of all the sub-tropical gyres. In the vicinity of Easter Island (Rapa Nui), the surface chlorophyll- $a$ concentration $(\mathrm{Chl}-a)$ is the lowest of the global open ocean with annual means as low as $0.019 \mathrm{mg} \mathrm{Chl-} a \mathrm{~m}^{-3}$ (Fig. 1a). These exceptionally low surface Chl- $a$ correspond to very clear waters with deep penetration not only of visible but also of UV radiations (Vasilkov et al., 2001). Interestingly, these hyperoligotrophic characteristics are also closely correlated with exceptional physical features (Fig. 1b). Actually, the pycnocline depth, derived from hydrological database, presents the largest values $(>200 \mathrm{~m})$ of the global ocean (Fig. 1b), precisely in the zone where the Chl- $a$ concentration is the lowest (Fiedler and Talley, 2006). This apparently tight coupling between the physical and biological fields reveals an extremely deep nutrient source and a weak upward diffusion of nutrient fuelling the phototrophic production in the surface layer. Furthermore, due to the weak source of iron-rich desert dust in the southern hemisphere, atmospheric iron deposition is low, particularly in the SPG. Modelling results suggest that the deposition rate could be at least one order of magnitude lower than in the northern hemisphere (Mahowald et al., 2005) (Fig. 1c). Therefore, the upper waters of the SPG are expected to receive, in comparison to other oceanic regions, the lowest nutrients fluxes from deeper layers as well as the lowest iron flux from the atmosphere.

In contrast to the SPG, the equatorial and subequatorial Pacific waters have received considerable attention, particularly during the nineties in the context of the JGOFS program (Murray et al., 1995; Murray et al., 1997; Dandonneau, 1999). The impact of physical (e.g. upwelling strength), chemical (e.g. iron supply) and biological (e.g. grazing pressure) factors on the carbon cycle have been investigated and quantified in detail (Murray et al., 1994). Furthermore, the analysis of time series permitted to begin documenting the effect of ENSO on the inter-annual variability of some specific biogeochemical processes (Yoder and Kennelly, 2003). At the regional scale, these subequatorial waters are referred to as High Nutrient Low Chlorophyll waters because they present some moderate oligotrophic characteristics associated with significant amounts of nitrate. However, at a more local scale and in the vicinity of steep islands, these oligotrophic conditions might be temporarily or permanently relieved. The enhancement of water productivity has been reported in particular for waters west of the Galapagos Archipelago (Martin et al., 1994), Kiribati Islands (Messié et al., 2006) and Marquesas Archipelago (Signorini et al., 1999; Martinez and Maamaatuaiahutapu, 2004). The reasons behind this enhancement of productivity are still debated and are investigated mostly through modelling or remote sensing. In particular, no in situ investigation has been carried out to date for the remote Marquesas Islands. 
The permanent upwelling associated with the PCC represents one of the most productive area of the global ocean (Carr, 2002) fuelling some of the largest fisheries. Despite this important biological and trophic impact, the PCC remains the least well known eastern boundary current system, both from their activity and phylogeny (Daneri and Quinones, 2001; Leth et al., 2004). As shown by Yuras et al. (2005), phytoplankton biomass covaries in phase with the upwelling-favorable winds along the Chilean coast while offshore phytoplankton biomass varies out of phase. This offshore biomass sometimes presents extreme westwards filamentous extension $(200-300 \mathrm{~km})$. These extensions are more important than what would be expected from the sole local dynamics of "wind driven" upwelling. The importance of mesoscale dynamics (meanders and gyres) and their interaction with the complex large scale circulation has therefore been proposed (Thomas et al., 1994; Leth and Shaffer, 2001) as regional specificities of SEP that might account for large offshore biomasses associated with these filaments.

\section{Objectives of the BIOSOPE program}

In 2001, after a whole decade of rather intensive field observations in various oceanic provinces as part of the JGOFS program, Daneri and Quinones wrote a contribution in the US JGOFS newsletter with a title clearly summarizing their concerns "Under sampled ocean systems: a plea for an international study of biogeochemical cycles in the Southern Pacific Gyre and its boundaries”. The BIOSOPE (BIogeochemistry and Optics South Pacific Experiment) program, jointly endorsed by the IMBER and SOLAS programs, was completely in line with this plea. Its overall goal was to explore and describe the biological, biogeochemical and optical characteristics of the South East Pacific. Using core measurements (in line with the former JGOFS core parameters) as well as new ones (e.g. based on the use of molecular biology and isotopic techniques, novel optical devices), two major goals were set.

1. Perform detailed studies in a certain number of oceanic provinces of the SEP in order to quantify the variables and processes that are essential to the understanding of trophic relationships, biogeochemical cycles of carbon and related elements as well as water optical signatures. The primary motivation of BIOSOPE was to study the South Pacific Gyre, expected to be the end member of oligotrophic conditions in the global ocean. But other SEP oceanic provinces were also of interest. The water masses west of Marquesas (local biomass enhancement visible from satellite) deserved to be investigated in the more general context of the HLNC conditions associated with the subequatorial area. Similarly, the upwelling zone extending offshore the Chilean coast was of great interest because of its particular filamentous patterns.
2. Understand in details the relationships linking optical properties of SEP waters to their biological and to biogeochemical characteristics. Besides surface Chl- $a$, an increasing number of biogeochemical or biological properties begin to be accessible from remote sensing (Ciotti and Bricaud, 2006; Uitz et al., 2006; Loisel et al., 2006; Siegel et al., 2002). The bio-optical models allowing the extraction of such "new products" still require validation and eventually refinement. A strong component of BIOSOPE was thus dedicated to optical and bio-optical studies. It was planned to elaborate a self consistent data base covering the complete range of trophic, biogeochemical and optical conditions that can be observable in open-ocean waters. Such a database would be invaluable to test and refine bio-optical models and eventually will allow identifying any peculiarity of the SEP with regard to other open ocean environments.

\section{Implementation of the cruise}

The BIOSOPE cruise took place during austral summer of 2004 (26 October-11 December), during a moderate phase of the El Nino Southern Oscillation ENSO ${ }^{1}$. The $\sim 8000 \mathrm{~km}$ transect, investigated with the French Research Vessel l'Atalante, started west of the Marquesas archipelago and ended off coastal waters of Chile (Fig. 2). Along this transect, two main types of stations (Table 1) were occupied, the so-called "short" and "long" stations.

The occupation of short stations, on a daily basis, had to cope with two main constraints. Sampling for biogeochemical flux measurements performed under simulated in situ conditions (e.g. production of the various biological stocks, nutrient assimilation) had to be performed two hours before sunrise while optical measurements had to be performed around noon in phase with satellite overpasses so that they could be used for ocean colour satellite validation. Consequently, the short stations generally consisted of two substations, station StA (before sunrise) and StB (around noon), generally spaced by $\sim 40$ miles $(\sim 4$ sailing hours apart). Certain measurements (CTD, other sensors, and some chemical measurements, e.g. nutrient and pigment concentrations) were systematically performed at both stations StA and StB. Their analyses confirm that, over the whole transect, the variability of StA vs StB remains extremely small (except for stations StA20 and StB20 in the vicinity of the Chilean coast) in comparison to the inter-station variability.

Six long stations were investigated for period longer than two days (Table 1), allowing the deployment of drifting moorings for sediment traps and production lines, and high frequency $(3 \mathrm{~h})$ repetitive sampling with the CTD-rosette. The position of four long stations was determined using realtime ocean colour data (SeaWiFS, MODIS, MERIS) looking

\footnotetext{
${ }^{1}$ see: http://www.ncdc.noaa.gov/oa/climate/research/2004/ann/ enso-monitoring.html
} 


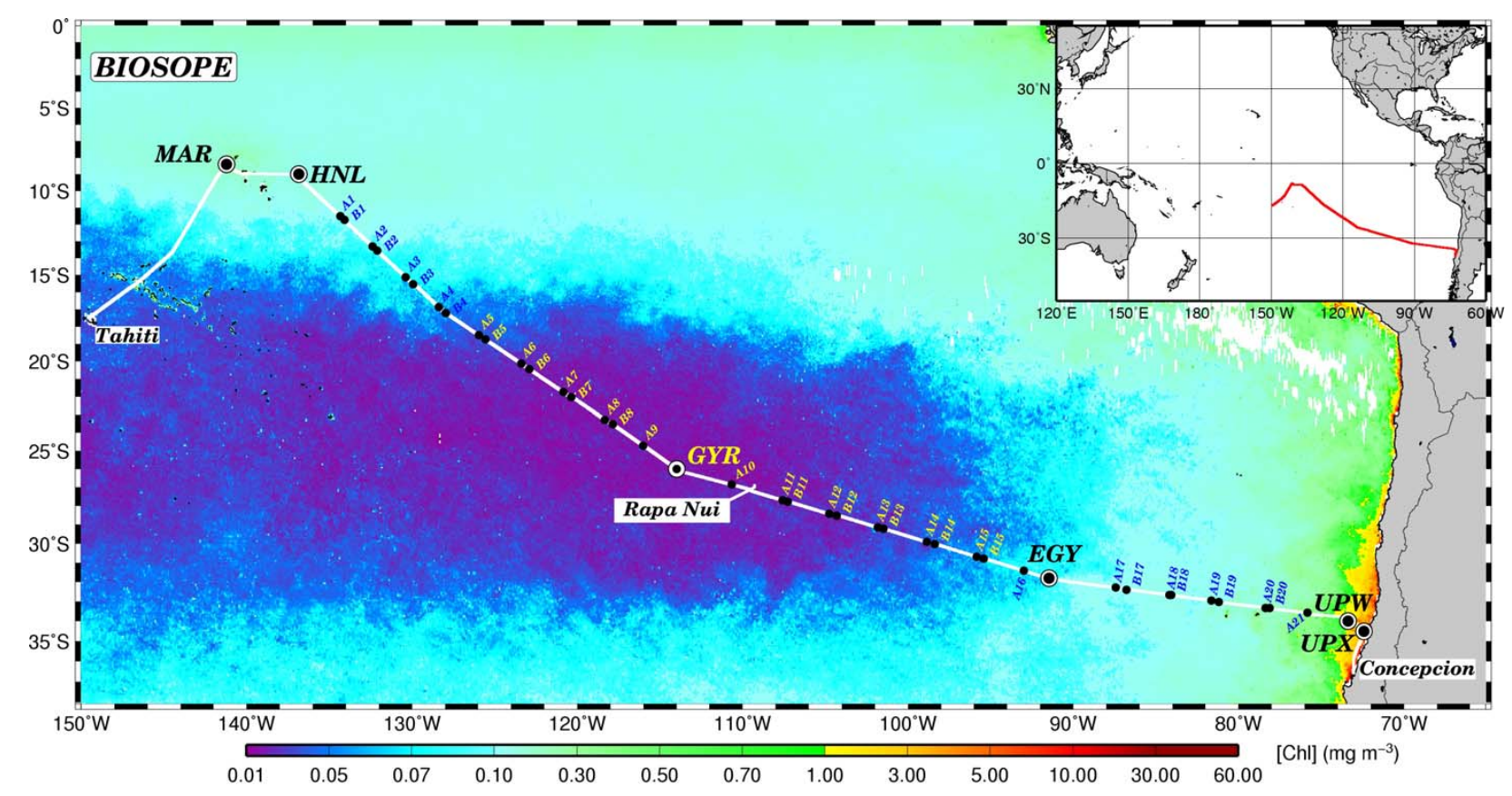

Fig. 2. Transect of the BIOSOPE cruise superimposed on a SeaWiFS composite image of Chl-a concentration in the upper layer for November-December 2004. The two main types of station, long and short, are indicated. The six long stations investigated for a period longer than 2 days are identified by a 3 letter code (see text). The 21 short stations are generally split into sub-stations A (early morning) and B (around noon). Four stations (referred as A9, A10, A16 and A21) did not follow this scheme. Note that the actual denomination for the short stations begins with St (Table 1), but the code has been simplified on this map to facilitate reading.

for the highest (MAR, west of Marquesas Island; UPW, UPX for the upwelling conditions off the Chile), and the lowest (GYR in the center of the South Pacific Gyre) surface Chl$a$ concentrations. It should be noted that the GYR station $\left(114^{\circ} \mathrm{W}, 26^{\circ} \mathrm{S}\right)$ is extremely close to the location $\left(115^{\circ} \mathrm{W}\right.$, $26^{\circ} \mathrm{S}$ ) of the most oligotrophic area of the global ocean identified from an historical analysis of SeaWiFS ocean colour data $^{2}$. The reference station for High Nutrient Low Chl- $a$ waters (HNL) in the subequatorial zone was set at the latitude of the Marquesas Archipelago, but east of it. Finally, the EGY station, located at the eastern border of the Gyre, was assumed to be representative of the transition zone between the South Pacific Gyre and the meridian branch of the anticyclonic circulation.

\section{Water masses in the South East Pacific}

4.1 The sub equatorial area: Marquesas to St2 $\left(142^{\circ} \mathrm{W}-\right.$ $132^{\circ} \mathrm{W}$ )

North of $14^{\circ} \mathrm{S}$, waters are under the influence of the equatorial regime. The eastward flowing South Equatorial Counter Current (SECC, $\sim 141^{\circ} \mathrm{W} ; 8^{\circ} \mathrm{S}$ ) is embedded in the west-

\footnotetext{
${ }^{2}$ see: http://earthobservatory.nasa.gov/Newsroom/NewImages/ images.php3?img_id=16409
}

wards flowing South Equatorial Current (SEC, $\sim 138^{\circ} \mathrm{W}$; $9^{\circ} \mathrm{S}$ ) (Fig. 3). At $143^{\circ} \mathrm{W}, 11^{\circ} \mathrm{S}$ a vein of the SEC is also recorded in the subsurface water (data not shown). The post-cruise trajectories of 3 profiling floats deployed west of $132^{\circ} \mathrm{W}$ confirm that the area is clearly under the influence of the SEC (Table 2). Surface waters are warm (up to $27^{\circ} \mathrm{C}$ ) and relatively fresh ( 35.6) (Fig. 4). In the Marquesas area, a rather homothermous layer of 70-100 m develops, delineated by a steep thermocline, and associated with weak water column stability (Brunt-Vaisala frequency, Fig. 3). Nutrient concentrations [see also Raimbault et al. (2008) for further details on nutrient distribution along the transect] are significant (nitrates $=1.88 \mu \mathrm{M}$ ) in surface around the Marquesas Islands (Fig. 5) and, in spite of a strong decreasing gradient, remain detectable until $132^{\circ} \mathrm{W}$ (nitrates $>0.3 \mu \mathrm{M}$ ). The distribution of in vivo fluorescence, a proxy of Chl- $a$, and of particle attenuation coefficient $\left(c_{p}\right)$, a proxy of particulate organic carbon (POC) are also uniform in this layer (Fig. 6). Moving eastwards, a sub-surface Chl- $a$ maximum develops at $\sim 70 \mathrm{~m}$ that lies on the pycnocline (station HLN- St1), while $c_{p}$ remains homogenous in this layer. Oligotrophic conditions start at $\mathrm{St} 2$ with the presence of a deep chlorophyll maximum (DCM) located at $\sim 120 \mathrm{~m}$. Below $(>300 \mathrm{~m})$, a noticeable signal of Chl- $a$ fluorescence higher than the other surface values observed during the transect is clearly associated with suboxic $\left(<50 \mu\right.$ mole $\left.\mathrm{kg}^{-1}\right)$ conditions (Fig. 6b). 
Table 1. Date and Location of the stations investigated along the BIOSOPE transect.

\begin{tabular}{|c|c|c|c|}
\hline station & Date & Longitude & Latitude \\
\hline MAR1 & 26 Oct. 2004 & -141.23 & -8.42 \\
\hline MAR2 & 27 Oct. 2004 & -141.27 & -8.39 \\
\hline MAR3 & 28 Oct. 2004 & -141.26 & -8.34 \\
\hline MAR4 & 29 Oct. 2004 & -141.27 & -8.32 \\
\hline HNL1 & 31 Oct. 2004 & -136.86 & -9.00 \\
\hline HNL2 & 1 Nov. 2004 & -136.89 & -9.01 \\
\hline HNL3 & 02 Nov. 2004 & -136.98 & -9.06 \\
\hline STA1 & 3 Nov. 2004 & -134.35 & -11.51 \\
\hline STB1 & 03 Nov. 2004 & -134.10 & -11.74 \\
\hline STA2 & 4 Nov. 2004 & -132.39 & -13.31 \\
\hline STB2 & 4 Nov. 2004 & -132.11 & -13.55 \\
\hline STA3 & 5 Nov. 2004 & -130.38 & -15.13 \\
\hline STB3 & 5 Nov. 2004 & -129.93 & -15.53 \\
\hline STA4 & 6 Nov. 2004 & -128.38 & -16.87 \\
\hline STB4 & 6 Nov. 2004 & -127.97 & -17.23 \\
\hline STA5 & 7 Nov. 2004 & -125.95 & -18.51 \\
\hline STB5 & 7 Nov. 2004 & -125.55 & -18.75 \\
\hline STA6 & 8 Nov. 2004 & -123.41 & -20.13 \\
\hline STB6 & 8 Nov. 2004 & -122.89 & -20.45 \\
\hline STA7 & 9 Nov. 2004 & -120.86 & -21.75 \\
\hline STB7 & 9 Nov. 2004 & -120.38 & -22.05 \\
\hline STA8 & 10 Nov. 2004 & -118.33 & -23.29 \\
\hline STB8 & 10 Nov. 2004 & -117.89 & -23.55 \\
\hline STA9 & 11 Nov. 2004 & -116.02 & -24.71 \\
\hline GYR1 & 12 Nov. 2004 & -114.00 & -26.00 \\
\hline GYR2 & 12 Nov. 2004 & -113.99 & -26.00 \\
\hline GYR3 & 13 Nov. 2004 & -114.02 & -26.02 \\
\hline GYR4 & 14 Nov. 2004 & -114.02 & -26.03 \\
\hline GYR5 & 15 Nov. 2004 & -114.01 & -26.06 \\
\hline GYR6 & 16 Nov. 2004 & -113.99 & -26.07 \\
\hline STA10 & 17 Nov. 2004 & -110.67 & -26.85 \\
\hline STA11 & 20 Nov. 2004 & -107.59 & -27.70 \\
\hline STB11 & 20 Nov. 2004 & -107.29 & -27.77 \\
\hline STA12 & 21 Nov. 2004 & -104.75 & -28.44 \\
\hline STB12 & 21 Nov. 2004 & -104.31 & -28.54 \\
\hline STA13 & 22 Nov. 2004 & -101.83 & -29.15 \\
\hline STB13 & 22 Nov. 2004 & -101.48 & -29.23 \\
\hline STA14 & 23 Nov. 2004 & -98.87 & -29.92 \\
\hline STB14 & 23 Nov. 2004 & -98.39 & -30.04 \\
\hline STA15 & 24 Nov. 2004 & -95.83 & -30.70 \\
\hline STB15 & 24 Nov. 2004 & -95.43 & -30.79 \\
\hline STA16 & 25 Nov. 2004 & -93.00 & -31.42 \\
\hline EGY1 & 25 Nov. 2004 & -91.47 & -31.82 \\
\hline EGY2 & 26 Nov. 2004 & -91.47 & -31.82 \\
\hline EGY3 & 27 Nov. 2004 & -91.44 & -31.85 \\
\hline EGY4 & 28 Nov. 2004 & -91.41 & -31.86 \\
\hline EGY5 & 29 Nov. 2004 & -91.41 & -31.90 \\
\hline EGY6 & 30 Nov. 2004 & -91.41 & -31.90 \\
\hline STA17 & 01 Dec. 2004 & -87.43 & -32.30 \\
\hline STB 17 & 1 Dec. 2004 & -86.78 & -32.40 \\
\hline STA18 & 2 Dec. 2004 & -84.21 & -32.67 \\
\hline STB18 & 2 Dec. 2004 & -84.07 & -32.68 \\
\hline STA19 & 3 Dec. 2004 & -81.64 & -32.95 \\
\hline STB19 & 3 Dec. 2004 & -81.20 & -33.02 \\
\hline STA20 & 4 Dec. 2004 & -78.37 & -33.32 \\
\hline STB20 & 4 Dec. 2004 & -78.12 & -33.35 \\
\hline STA21 & 5 Dec. 2004 & -75.84 & -33.58 \\
\hline UPW1 & 6 Dec. 2004 & -73.37 & -34.00 \\
\hline UPW2 & 7 Dec. 2004 & -73.39 & -33.98 \\
\hline UPW3 & 8 Dec. 2004 & -73.34 & -33.86 \\
\hline UPX1 & 9 Dec. 2004 & -72.42 & -34.51 \\
\hline UPX2 & 10 Dec. 2004 & -72.43 & -34.58 \\
\hline UPX3 & 11 Dec. 2004 & -72.49 & -34.69 \\
\hline
\end{tabular}

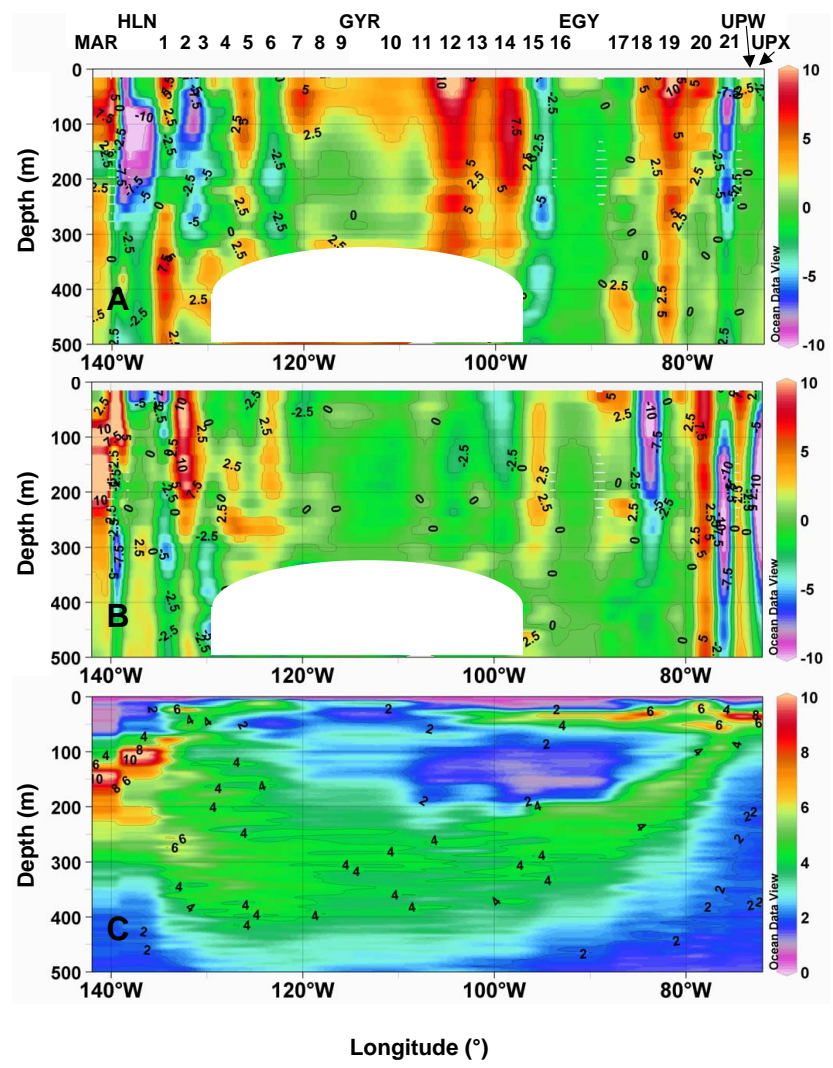

Fig. 3. Currents and Brunt-Väisälä frequency along the BIOSOPE transect. (a) Zonal component $\left(\mathrm{cm} \mathrm{s}^{-1}\right)$ : purple is westward and red is eastward. (b) Meridional component $\left(\mathrm{cm} \mathrm{s}^{-1}\right)$ : red is northward and purple is southward. (c) Brunt- Väisälä frequency (cyc $\mathrm{h}^{-1}$ ). No current was monitored in the masked area (no echo for the $75 \mathrm{Khz}$ RDI ADCP because of the very low level of particles in this layer).

This relative oxygen minimum likely reflects the signature of a north-westwards propagation of the oxygen minimum zone developing along South America (Fiedler and Talley, 2006). At this location, these suboxic conditions might also affect the degradation of particulate matter sinking from the upper layers.

4.1.1 The transition zone between the sub Equatorial area and the SPG (St2 to St6: $\left.132^{\circ} \mathrm{W}-123^{\circ} \mathrm{W}\right)$.

In the surface/sub-surface layer of this area, the so-called South Tropical Surface Waters (STSW) (Fiedler and Talley, 2006) are clearly characterized by a very high salinity (Figs. $4 \mathrm{~b}$ and 7), actually the highest of the Pacific (Tomczak and Godfrey, 2001), with the 36.5 isohaline being detected near the surface at $128^{\circ} \mathrm{W}, 15^{\circ} \mathrm{S}$. These salty waters result from evaporation strongly exceeding precipitation (Tomczak and Godfrey, 2001). The area does not present any noticeable currents (Fig. 3), which is confirmed by the moderate displacement of the two profiling floats deployed 
Table 2. ARGO floats deployed along the BIOSOPE transect. The left column refers to the 5 main zones defined in the paper.

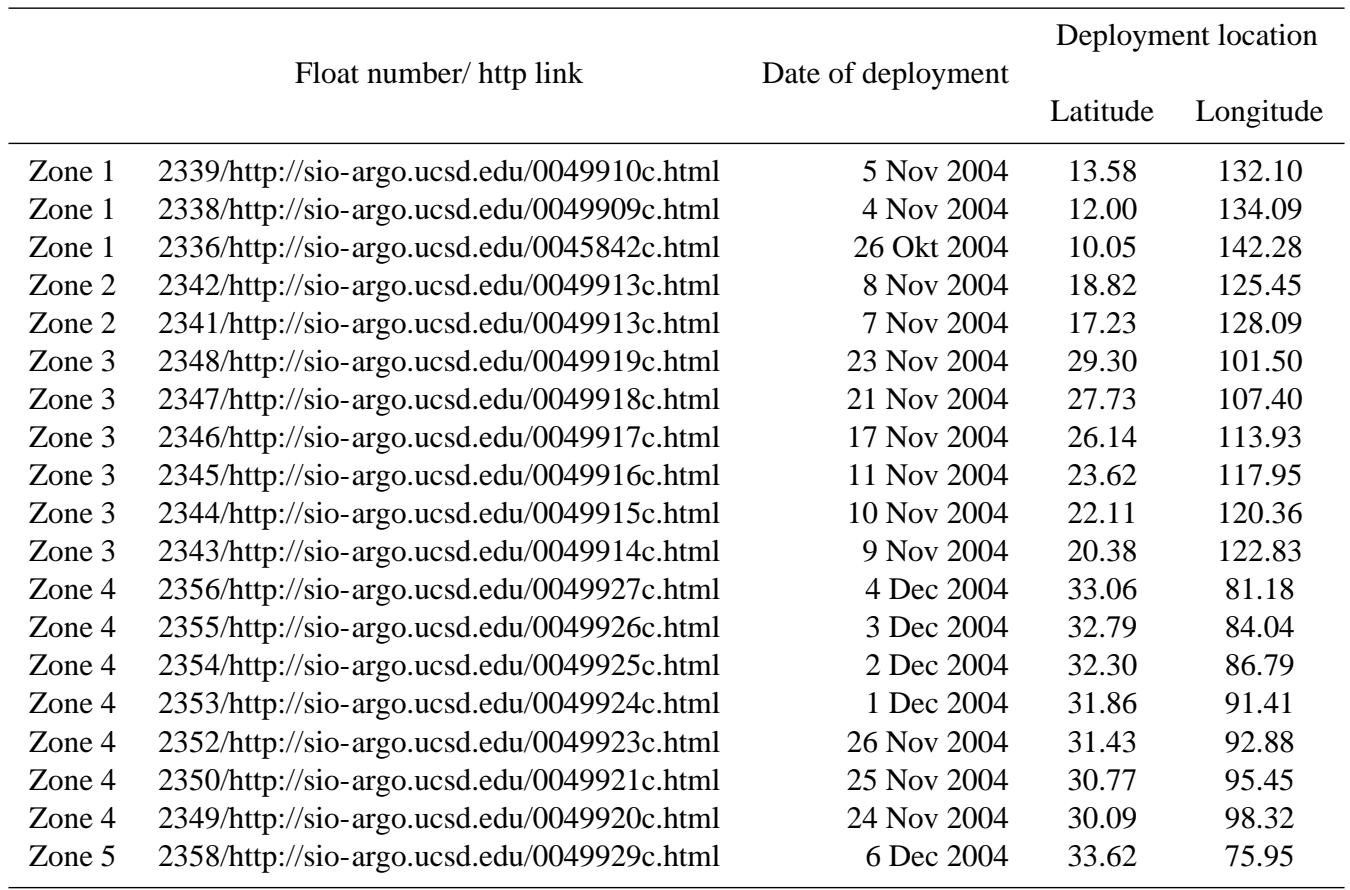

in this region (Table 2, floats \#2341, \#2342). This zone is also characterized by increasing oligotrophic conditions with the deepening of the nutricline. Nitrates are totally depleted $(<3 \mathrm{nM})$ in the $0-100 \mathrm{~m}$ water column, while phosphates and silicates are still detectable $(0.1$ and $1 \mu \mathrm{M}$, respectively). The DCM deepens very markedly eastward $(\sim 170 \mathrm{~m}$ at station 6). This is associated with a strengthening of the permanent thermocline, a consequence of the deepening of the sub-surface isotherm (e.g. the $15^{\circ} \mathrm{C}$ isotherms deepens from 240 to $320 \mathrm{~m})$. In the deeper layer $(>300 \mathrm{~m})$ the fluorescence signal as well as the suboxic conditions observed north-westwards are clearly vanishing.

\subsubsection{The central part of the SPG: (St6 to St13: $123^{\circ} \mathrm{W}-$ $\left.101^{\circ} \mathrm{W}\right)$}

The central part of the gyre is characterized by the strongly stratified Eastern South Pacific Central Waters (ESPCW) (Emery and Meincke, 1986) that cover a wide range of temperature and salinity values (Fig. 7) and correspond to the water masses associated with the permanent thermocline (Tomczak and Godfrey, 2001). This area is delineated by extremely low levels of Chl- $a$ fluorescence in the surface layer ( $\sim 0.02 \mathrm{mg} \mathrm{Chl}-a \mathrm{~m}^{-3}$ ) (Fig. 6) as well as by an extremely deep DCM which lies in the 160-200 m range over a distance of $\sim 2500 \mathrm{~km}$. The DCM position appears to be mainly driven by the density field (the base of the DCM follows the $26 \mathrm{~kg} \mathrm{~m}^{-3}$ isopycnal). The lowest levels of $c_{p}$ in the 0-200 $\mathrm{m}$ layer are recorded in this region, especially at sta- tion 6, 7 and 8. No inorganic nitrogen is a priori available for the biological production throughout the $0-150 \mathrm{~m}$ water column (nitrates $<3 \mathrm{nM}$ ). In contrast, both phosphates and silicates are always present at significant concentrations $(0.1$ and $1 \mu \mathrm{M}$, respectively). In the eastern part of the zone, on each side of $100^{\circ} \mathrm{W}$, two eastward flowing current veins represent probably the signature of the South Pacific Current (west wind drift) which splits in two bands (Stramma et al., 1995) and delineates the northern limit of the Subtropical Front, also identified by the strong salinity gradient at $\sim 100^{\circ} \mathrm{W}$. Mesoscale features related to Rossby waves (e.g. Wang et al., 1998) may also explain these current patterns. The six profiling floats deployed in this zone remained in a very restricted region (displacement of only a few degrees in latitude or longitude) over a three-year period (Table 2).

4.1.3 The transition zone between the SPG and the coastal upwelling area (St13 to St19: $100^{\circ} \mathrm{W}-81^{\circ} \mathrm{W}$ )

East of $100^{\circ} \mathrm{W}$, the transition zone between the salty ESPCW and the waters influenced by fresher Subantarctic Surface Waters (SASW) (Emery and Meincke, 1986; Tomczak and Godfrey, 2001) (Fig. 7) clearly delineates the core of the subtropical front (Chaigneau and Pizarro, 2005b). This zone also corresponds to a shoaling of the DCM which is located at $80 \mathrm{~m}$ at EGY station $\left(91^{\circ} \mathrm{W} ; 32^{\circ} \mathrm{S}\right)$ and of the nutriclines (e.g. the $0.1 \mu \mathrm{M} \mathrm{NO}_{3}$ isoline rises from $160 \mathrm{~m}$ at $\mathrm{St}$ 13 to $30 \mathrm{~m}$ at EGY). East of EGY (stations 17 to 19) HLNC conditions are observed with surface nitrates $>2.5 \mu \mathrm{M}$ and 


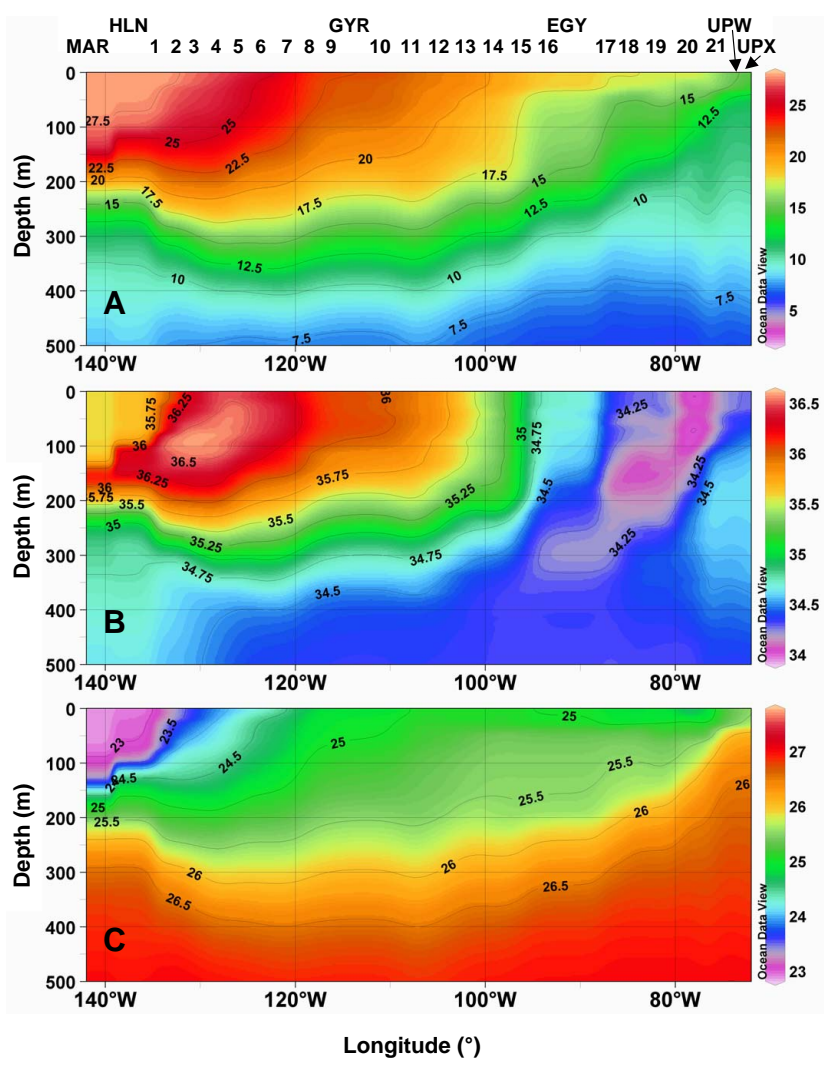

Fig. 4. Hydrological section along the BIOSOPE transect. (a) Potential temperature $\left({ }^{\circ} \mathrm{C}\right)$. (b) Salinity. (c) Potential density $\left(\mathrm{kg} \mathrm{m}^{-3}\right)$.

surface Chl- $a<0.2 \mathrm{mg} \mathrm{m}^{-3}$ ( $<0.1$ for St 19). At this location, a tongue of low salinity waters observed at a depth of $300 \mathrm{~m}$ progressively uplifts in an easterly direction and outcrops at the surface (salinity 34 ) at $78^{\circ} \mathrm{W} 33^{\circ} \mathrm{S}$. Here, the waters present the highest oxygen saturation levels of the whole transect. This location, at the south-eastern edge of the SPG, corresponds to the source of the South Pacific Intermediate Water, ESPIW, (Emery and Meincke, 1986), which then spreads north-westwards into the intermediate layer of the SPG (Schneider et al., 2003) and transfers the surface water properties of the waters off central Chile to tropical latitudes.

\subsubsection{The coastal upwelling area (St19 to UPX: east of} $\left.81^{\circ} \mathrm{W}\right)$

East of $78^{\circ} \mathrm{W}$, the ESPIW lies above the relatively saltier (>34.5) Equatorial Subsurface Water (EESW) (Blanco et al., 2001) which extends in the $100-400 \mathrm{~m}$ range and is part, especially when approaching the Chilean coast, of the poleward Peru-Chile undercurrent (PCUC). The PCUC presents two veins at this location (Fig. 3) that have their velocity maximum at $\sim 250 \mathrm{~m}$. Two $(0-500 \mathrm{~m})$ veins of the equatorward PCC are also embedded with the PCUC illustrating the

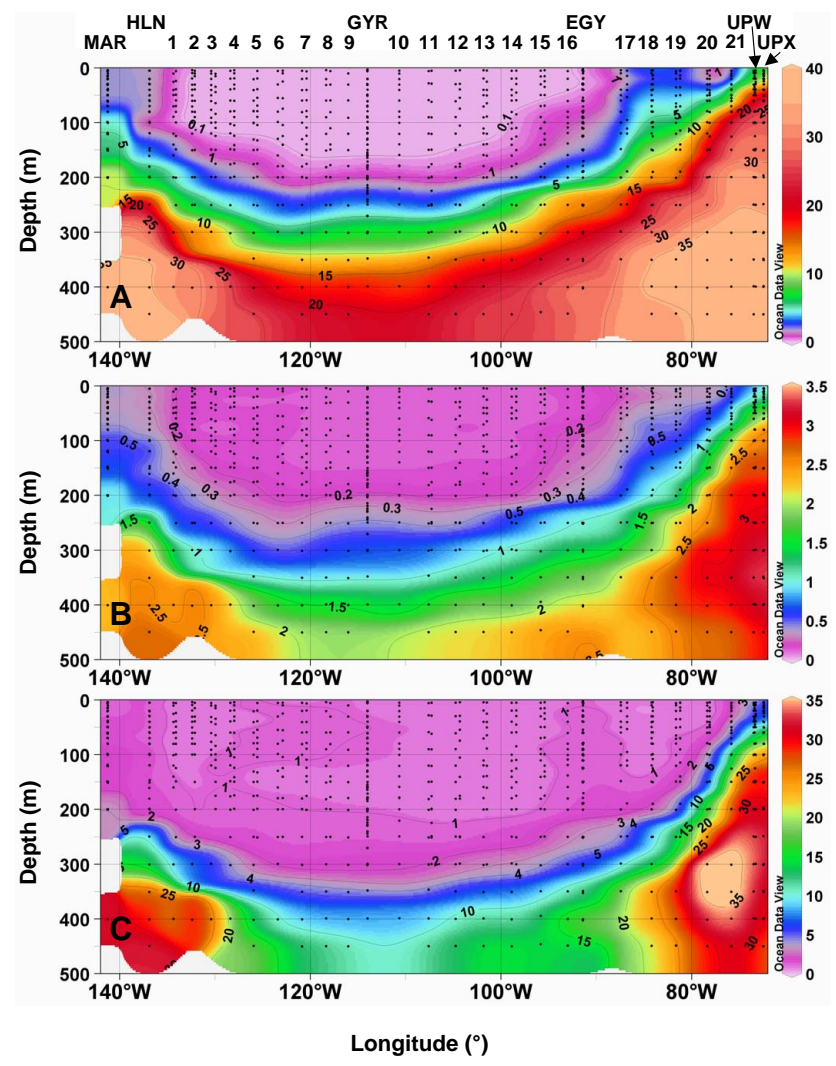

Fig. 5. Nutrient concentrations $\left(\mu M l^{-1}\right)$ along the BIOSOPE transect. (a) Nitrate $\left(\mathrm{NO}_{3}\right)$. (b) Phosphates $\left(\mathrm{PO}_{4}\right)$. (c) Silicates $\left(\mathrm{Si}(\mathrm{OH})_{4}\right)$.

complexity of the circulation in the water off Chile (Shaffer et al., 1995). The only float deployed in this area $\left(\sim 76^{\circ} \mathrm{W}\right.$; \#2358, Table 2) presented a clear northern drift during the December 2004-December 2006 period. In the surface layer, the shoaling and the narrowing of the isotherms allow the delineation of a reduced mixed layer $(\sim 15-20 \mathrm{~m})$ where the highest nutrient concentrations (nitrates up to $15 \mu \mathrm{M}$ in surface) as well as the highest Chl- $a$ fluorescence (corresponding to $3 \mathrm{mg} \mathrm{Chl}-a \mathrm{~m}^{-3}$ ) and $c_{p}$ signal are recorded. The intermediate layer where PCUC predominates is clearly associated with suboxic conditions and with a very significant signal of "deep" Chla fluorescence.

\section{Special issue presentation}

The goal of this special issue is to present the knowledge gained concerning the South East Pacific based on the large dataset acquired during the BIOSOPE cruise. Although a disciplinary approach around three main topics (biology, biogeochemistry and optics) was adopted for data acquisition, many questions relevant to this project have benefited from multidisciplinarity. The cruise strategy as well as onboard experimental design has been organized to promote 


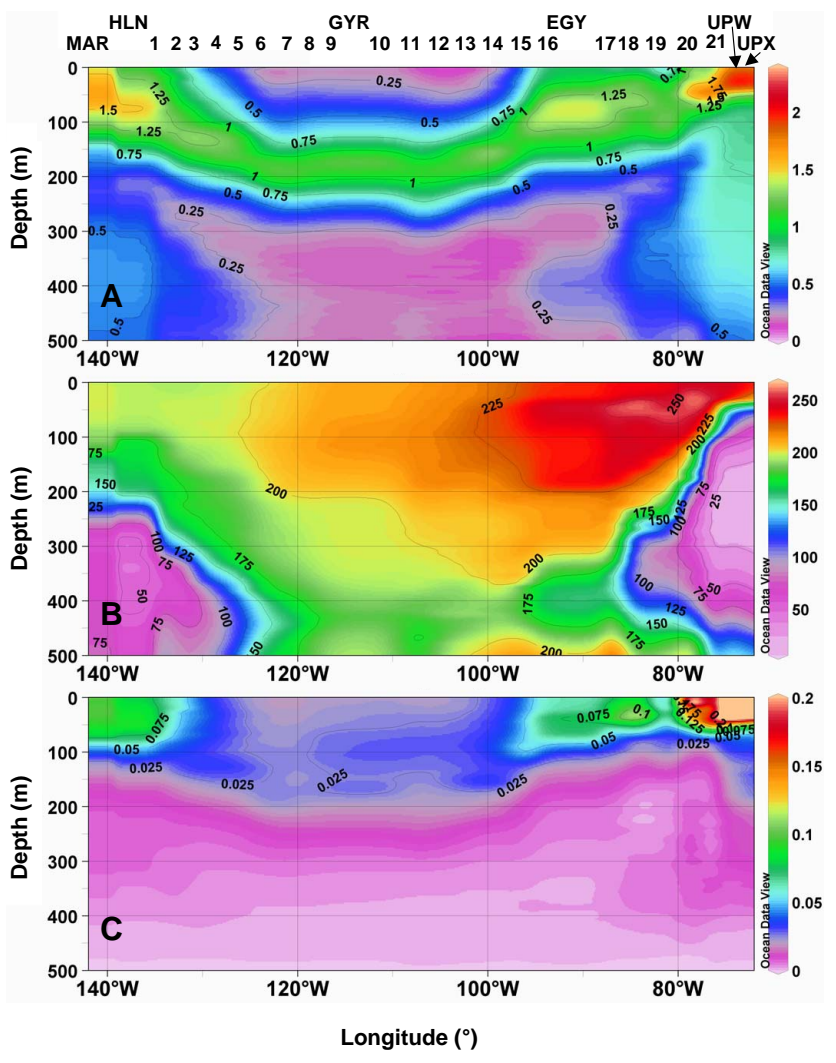

Fig. 6. Distribution of specific biogeochemical and optical properties along the BIOSOPE transect. (a) In vivo fluorescence of Chl- $a$ (V). (b) Oxygen concentration $\left(\mu \mathrm{M} \mathrm{kg}^{-1}\right)$. (c) attenuation coefficient, $c_{p}\left(\mathrm{~m}^{-1}\right)$. The attenuation coefficient data have been processed as described in Claustre et al. (2007), by correcting for deep (450-500 m) values.

and favour such a synergic approach. Therefore, even if papers from this special issue (and for some others published elsewhere) are introduced below according to disciplines, most of the contributions have taken advantage of this collective effort so that paper scopes are often multidisciplinary too. Finally, it should be noted that some papers compare data acquired within the SEP with data acquired with similar techniques in other oceanic provinces. These papers represent a first step in revealing the existence (or the lack) of specificities of SEP waters with respect to other environments.

\subsection{Biology and biodiversity}

The very large trophic gradient that was extensively sampled during the BIOSOPE cruise offered a unique opportunity to better understand how the structure of biological communities in the open ocean adapts to varying nutrient conditions, with a specific focus on the extremely oligotrophic conditions of the central SPG. It is expected that under such conditions, the community structure shifts towards very small

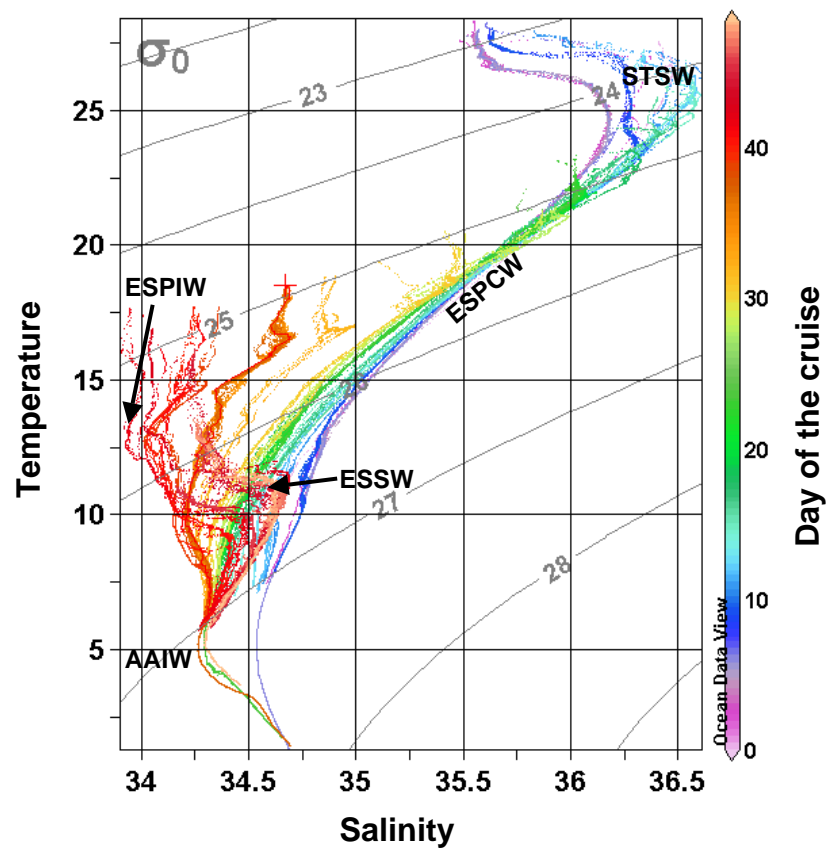

Fig. 7. Temperature-salinity diagram and identification of the main waters masses encountered along the BIOSOPE transect. STSW : South Tropical Surface Waters ; ESPCW : Eastern South Pacific Central Waters; ESPIW: South Pacific Intermediate Water; EESW : Equatorial Subsurface Water; AAIW: Antarctic Intermediate Waters. The colour code refers to the day of the mission starting near Marquesas Archipelago (purple) and ending along the Chilean Coast (red). 224 CTD casts are used for this plot. Except for four deep casts (down to the sea floor), the other ones were performed down to $500 \mathrm{~m}$.

cell sizes and that the microbial loop becomes dominant. However, whether the extreme conditions (e.g. depth of the DCM and relative isolation of the SPG waters) have favoured the establishment of yet unknown communities and microorganisms is an intriguing possibility.

The autotrophic community was analysed in detail using different approaches, some of which are quite novel. The overall distribution of phytoplankton communities was assessed from HPLC pigment signatures and compared to distribution modelled from statistical relationships for the global ocean in order to highlight SEP peculiarities (Ras et al., 2008). Grob et al. (2007) relied on flow cytometry to determine the distribution of picoplankton and its impact on POC and on the particle attenuation coefficient. Masquelier and Vaulot (2008) used epifluorescence microscopy to look at picoplanktonic groups such as cyanobacteria (in particular those forming colonies), autotrophic picoeukaryotes, but also at larger protists such as ciliates and dinoflagellates (in particular some displaying intriguing green autofluorescence that are particularly abundant in this area). The diversity of picophytoplankton was assessed by novel culturing approaches (Le Gall et al., 2008). Beaufort et al. (2007) 
investigated another important autotrophic group, the coccolithophorids, and in particular their impact on calcite production in the SEP.

With respect to larger autotrophs, the relation between the physico-chemical conditions and the composition of the diatom assemblage in two different HNLC conditions, the tropical central Pacific and the offshore Peru-Chile Current, was examined by Gómez et al. (2007). Numerous contributions to the knowledge of dinoflagellates, a group of special relevance in warm oligotrophic oceans have been presented in other journals (Gómez, 2006; Gómez, 2008a; Gómez, 2008b; Gómez, 2007a; Gómez and Furuya, 2007).

During BIOSOPE, heterotrophic bacteria have been studied in great details from the point of view of their production relative to primary production along the trophic gradient (Van Wambeke et al., 2008) and of the factor(s) regulating this production both spatially (Van Wambeke et al., 2007a) and temporally, with a special focus on the diel cycle and UV impact at long stations (Van Wambeke et al., 2007b). The relationship between bacteria and available sugars was investigated by Sempéré et al. (2008), while a new approach, based on the incorporation of labelled phosphorus into phospholipids, allowed showing that heterotrophic bacteria play a critical role in the phosphorus cycle, especially in the SPG (Van Mooy et al., 2008). The very specific bacterial community of the surface microlayer has been assessed both from the phylogenetic and activity points of view by Obernosterer et al. (2007).

Heterotrophic eukaryotes play a key role in recycling the organic matter from the microbial food web. The diversity of tintinnids was investigated with respect to the phytoplankton prey by Dolan et al. (2007) and follows on other recent descriptions of this microzooplankton group in the SEP (Dolan, 2006). The symbiotic association between the diatom Chaetoceros and the tintinnid Eutintinnus was investigated as an example of microplankton adaptation to the severe oligotrophic conditions (Gómez, 2007b). Microscope observations have also allowed elucidating the mysterious nature of the consortia between the protozoan Solenicola and the frustule of the diatom Leptocylindrus mediterraneus (Gómez, 2007c).

\subsubsection{Biogeochemistry}

Two "greenhouse" gases have been the subject of dedicated studies during BIOSOPE. Azouzi et al. (2007) provided an analysis of anthropogenic $\mathrm{CO}_{2}$ penetration in the SEP and compared it with earlier estimates of anthropogenic tracers. Charpentier et al. (2007) focused on the processes of $\mathrm{N}_{2} \mathrm{O}$ production and showed differences in the saturation level as well as in the source of this gas according to the hydrodynamic and associated trophic regimes considered. Nitrogen cycle was further addressed in Raimbault and Garcia (2008) who showed, in particular, that nitrogen fixation, while extremely low in the SPG, nevertheless sustained most of new production in this area. This extremely weak nitrogen fixation was supported by extremely low abundance of the cyanobacterial nifH gene (Bonnet et al., 2008). Iron which is an essential element for life, in particular for nitrogen fixation, is vanishing low in the top $350 \mathrm{~m}(\sim 0.1 \mathrm{nM})$ (Blain et al., 2008) which confirmed the extremely low atmospheric deposition recorded by Wagener et al. (2008). As a result of low iron concentration and low nitrogen fixation, phosphate concentration in surface layers was always above a threshold of $0.1 \mu \mathrm{M}$ (Raimbault et al., 2008) and thus never constituted a limiting element for phytoplankton growth (Moutin et al., 2008), even in the hyperoligotrophic conditions of the SPG. A new method based on simultaneous spiking of water samples with ${ }^{33} \mathrm{P}$ and ${ }^{14} \mathrm{C}$ allowed to measure autotrophic and bacterial contribution for various size fractions and suggested that the microbial community turns over very slowly (Duhamel et al., 2007). Primary production measurement using ${ }^{13} \mathrm{C}$ labelling confirmed extremely low rates in the core of the SPG $\left(100 \mathrm{mg} \mathrm{C}^{-2} \mathrm{~d}^{-1}\right)$. These results were however partly contradictory with the bacterial carbon demand estimated by Van Wambeke et al. (2008). An optical technique based on the diel cycle in the attenuation coefficient (Claustre et al., 2008) suggested that rates of community production are much higher than expected and could result fromexceptional DOC release during photosynthetic processes. This DOC release, unfortunately not measured during the cruise, might explain part of the discrepancies between bacterial carbon demand and production rates using various methods.

A new approach for particle flux determination, based on the optical quantification of particles forming the stock of large particulate matter (LPM $>90 \mu \mathrm{m}$ ) was validated against the sediment trap fluxes at the six long stations and then applied along the whole BIOSOPE transect (Guidi et al., 2008). Significant diel variations in concentration and spectral slope of the particle size distribution were observed for particles smaller than $100 \mu \mathrm{m}$, but not for LPM (Stemmann et al., 2008). Finally, detailed characterization of the nature of the particle material was achieved using a combination of lipid biomarkers and carbon isotopic ( $\delta 13)$ composition (Tolosa et al., 2007).

\subsection{Optics and bio-optics}

The hyperoligotrophic conditions encountered in the centre of the gyre during BIOSOPE offered the opportunity to improve our knowledge of pure water optical properties by (1) setting upper limits to pure water absorption, especially in the UV range (Morel et al., 2007b) and (2) investigating in great detail backscattering properties by pure water (Twardowski et al., 2007) and permitting the evaluation of different values proposed for this coefficient. Furthermore (Morel et al., 2007a) highlighted optical singularities of Pacific waters when compared to Mediterranean waters, especially in the short wavelength domain including UV and for low Chl$a$. The high penetration of UV radiation in the SPG was also 
confirmed by (Tédetti et al., 2007). Additionally, previously published model of the so-called bi-directional effects in water upwelling radiances was validated for the first time in these extremely clear waters (Voss et al., 2007). Supplementing the BIOSOPE data-base with data from the eastern Atlantic Stramski et al. (2008) evaluate several approaches for quantifying particulate organic carbon concentration in surface waters from the determination of certain optical properties. Huot et al. (2008) built upon the unique optical measurements of Stramski et al. (2008) and Twardowski et al. (2007) to establish a relationship between the spectral backscattering coefficient and the Chl- $a$ concentration and to examine the variations of the backscattering ratio with trophic status. Huot et al. (2007) evaluateed the validity of various optical proxies of phytoplankton biomass, either derived from space or from in situ measurement, for the estimation of photophysiological parameters used in bio-optical modelling of primary production. Finally, optical measurements made during BIOSOPE were also used by Uitz et al. (2008) to describe the photosynthetic characteristics of different phytoplankton groups and parameterize them for use in primary production models, and by Brown et al. (2008) to evaluate a new approach to estimate, from remotely sensed ocean colour, the concentration of substances other than Chl- $a$.

\section{Final note: the evaluation process and the role of guest editors}

All papers published in this special issue have been evaluated according to the normal procedure used for regular issues of Biogeosciences. In particular, none of the three BIOSOPE guest editors did intervene at any stage of manuscript evaluation. Their role was restricted to the revision of manuscripts prior to submission and to the coordination of the various submissions (ensuring consistency between the various manuscripts). For each manuscript, the BIOSOPE guest editors have provided a list of four to five potential referees which may or may not have been used by the regular Biogeosciences editors. Therefore, papers published in this BIOSOPE special issue comply with the general quality standards of Biogeosciences.

Acknowledgements. This BIOSOPE project was funded by the Centre National de la Recherche Scientifique (CNRS), the Institut des Sciences de l'Univers (INSU), the Centre National d'Etudes Spatiales (CNES), the European Space Agency (ESA), The National Aeronautics and Space Administration (NASA) and the Natural Sciences and Engineering Research Council of Canada (NSERC). This is a contribution to the BIOSOPE project of the LEFE-CYBER program. Dominique Tailliez and Claudie Bournot are warmly thanked for their efficient help in CTD management and data processing, Gérard Eldin for processing ADCP data. Drs Fiedler and Mahowald are warmly thanked for allowing getting access to their data used in Fig. 1 of this paper.

Edited by: S. Pantoja

\section{References}

Azouzi, L., Ito, R. G., Touratier, F., and Goyet, C.: Anthropogenic carbon in the eastern south Pacific Ocean, Biogeosciences Discuss., 4, 1815-1837, 2007,

http://www.biogeosciences-discuss.net/4/1815/2007/.

Beaufort, L., Couapel, M., Buchet, N., and Claustre, H.: Calcite production by coccolithophores in the south Pacific Ocean: from desert to jungle, Biogeosciences Discuss., 4, 3267-3299, 2007, http://www.biogeosciences-discuss.net/4/3267/2007/.

Blain, S., Bonnet, S., and Guieu, C.: Dissolved iron distribution in the tropical and sub tropical South Eastern Pacific, Biogeosciences, 5, 269-280, 2008, http://www.biogeosciences.net/5/269/2008/.

Blanco, J. L., Thomas, A. C., Carr, M. E., and Strub, P. T.: Seasonal climatology of hydrographic conditions in the upwelling region off northern chile, J. Geophys. Res., 106, 11 451-411 468, 2001.

Bonnet, S., Guieu, C., Bruyant, F., Prášil, O., Van Wambeke, F., Raimbault, P., Moutin, T., Grob, C., Gorbunov, M. Y., Zehr, J. P., Masquelier, S. M., Garczarek, L., and Claustre, H.: Nutrients limitation of primary productivity in the southeast pacific (BIOSOPE cruise), Biogeosciences, 5, 215-225, 2008, http://www.biogeosciences.net/5/215/2008/.

Bouman, H. A., Ulloa, O., Scanlan, D., Zwirglmaier, K., Li, W. K. W., Platt, T., Stuart, V., Barlow, R. G., Leth, O., Clementson, L. A., Lutz, V. A., Fukasawa, M., Watanabe, S., and Sathyendranath, S.: Oceanographic basis of the global surface distribution of prochlorococcus ecotypes., Science, 312, 918-921, 2006.

Brown, C., Huot, Y., Werdell, P. J., Gentili, B., and Claustre, H.: The origin and global distribution of second order variability in satellite ocean color, Remote Sensing of Environment, in revision, 2008.

Carr, M. E.: Estimation of potential productivity in eastern boundary currents using remote sensing, Deep-Sea Res. II, 49, 59-80, 2002.

Chaigneau, A. and Pizarro, O.: Mean surface circulation and mesoscale turbulent flow characteristics in the eastern south pacific from satellite tracked drifters, J. Geophys. Res.-Oceans, 110, C05014, doi:10.1029/2004JC002628, 2005a.

Chaigneau, A. and Pizarro, O.: Surface circulation and fronts of the south Pacific Ocean, east of $120^{\circ}$ w, Geophys. Res. Lett., 32, L08605, doi:10.1029/2004GL022070, 2005b.

Charpentier, J., Farias, L., Yoshida, N., Boontanon, N., and Raimbault, P.: Nitrous oxide distribution and its origin in the central and eastern South Pacific Subtropical Gyre, Biogeosciences, 4, 729-741, 2007, http://www.biogeosciences.net/4/729/2007/.

Chavez, F. P., Buck, K. R., Bidigare, R. R., Karl, D. M., Hebel, D., Latasa, M., Campbell, L., and Newton, J.: On the chlorophyll a retention properties of glass-fiber gf/f filters, Limnol. Oceanogr., 40, 428-433, 1995.

Ciotti, A. M. and Bricaud, A.: Retrievals of a size parameter for phytoplankton and spectral light absorption by colored detrital matter from water-leaving radiances at seawifs channels in a continental shelf region off brazil, Limnology and Oceanography Methods, 4, 237-253, 2006.

Claustre, H., and Maritorena, S.: The many shades of ocean blue, Science, 302, 1514-1515, 2003.

Claustre, H., Huot, Y., Obernosterer, I., Gentili, B., Tailliez, D., and Lewis, M. R.: Gross community production and metabolic bal- 
ance in the South Pacific Gyre, using a non intrusive bio-optical method, Biogeosciences, 5, 463-474, 2008,

http://www.biogeosciences.net/5/463/2008/.

Dandonneau, Y.: Introduction to the special section: Biogeochemical conditions in the equatorial Pacific in late 1994, J. Geophys. Res., 104, 3291-3295, 1999.

Daneri, G. and Quinones, R. A.: Undersampled ocean systems: A plea for an international study of biogeochemical cycles in the southern Pacific gyre and its boundaries, US JGOFS Newsletter, January 2001, 9, 2001.

Dolan, J. R.: Re-discovered beauty - new images for old, descriptions - tropical tintinnids of the genus, xystonellopsis (ciliophora, tintinnia), Protist, 57, 251-253, 2006.

Dolan, J. R., Ritchie, M. E., and Ras, J.: The "neutral" community structure of planktonic herbivores, tintinnid ciliates of the microzooplankton, across the se tropical Pacific Ocean, Biogeosciences, 4, 297-310, 2007, http://www.biogeosciences.net/4/297/2007/.

Duhamel, S., Moutin, T., Van Wambeke, F., Van Mooy, B. A. S., Rimmelin, P., Raimbault, P., and Claustre, H.: Growth and specific p-uptake rates of bacterial and phytoplanktonic communities in the Southeast Pacific (BIOSOPE cruise), Biogeosciences, 4, 941-956, 2007, http://www.biogeosciences.net/4/941/2007/.

Eldin, G.: Eastward flows of the South Equatorial Central Pacific, Journal of Physical Oceanography, 13, 1461-1467, 1983.

Emery, W. J. and Meincke, J.: Global water masses: Summary and review, Oceanologica Acta, 9, 383-391, 1986.

Fiedler, P. C. and Talley, L. D.: Hydrography of the Eastern Tropical Pacific: A review, Progress In Oceanography, 69, 143-180, 2006.

Forgsbergh, E. D. and Joseph, J.: Phytoplankton production in the South-eastern Pacific, Nature, 200, 87-88, 1963.

Gómez, F.: The dinoflagellate genera Brachidinium, Asterodinium, Microceratium and Karenia in the open SE Pacific Ocean, Algae, 21, 445-452, 2006.

Gómez, F.: On the consortium of the tintinnid Eutintinnus and the diatom Chaetoceros in the Pacific Ocean, Marine Biology, 18991906, 2007b.

Gómez, F.: Gymnodinioid, Dinoflagellates (gymnodiniales, dinophyceae) in the open Pacific Ocean, Algae, in press, 2008a.

Gómez, F.: The consortium of the protozoan Solenicola setigera and the diatom Leptocylindrus mediterraneus in the Pacific Ocean, Acta Protozoologica, 46, 15-24, 2007c.

Gómez, F.: New records of the dinoflagellate genus Dicroerisma (Actiniscales, Dinophyceae) in the Pacific Ocean Chinese Journal of Oceanology and Limnology, in press, $2008 \mathrm{~b}$.

Gómez, F.: Nuevos registros del dinoflagelado Craspedotella kofoid, 1905 (Dinophyceae: Noctilucales) en el Océano Pacífico., Revista de Biología Marina y Oceanografía, 42, 83-87, 2007a.

Gómez, F., Claustre, H., Raimbault, P., and Souissi, S.: Two highnutrient low chlorophyll phytoplankton assemblages: The tropical central pacific and the offshore Perú-Chile current, Biogeosciences, 4, 1101-1113, 2007,

http://www.biogeosciences.net/4/1101/2007/.

Gómez, F. and Furuya, K.: Kofoidinium, Spatulodinium and other Kofoidiniaceans (Noctilucales, Dinophyceae) in the Pacific Ocean, European Journal of Prostitology, 43, 115-124, 2007.

Grob, C., Ulloa, O., Li, W. K. W., Alarcon, G., Fukasawa, M., and Watanabe, S.: Picoplankton abundance and biomass across the eastern south Pacific Ocean along $32.5^{\circ} \mathrm{S}$, Marine Ecology Progress Series, 332, 53-62, 2006.

Grob, C., Ulloa, O., Claustre, H., Huot, Y., Alarcon, G., and Marie, D.: Contribution of picoplankton to the total particulate organic carbon concentration in the eastern South Pacific, Biogeosciences, 4, 837-852, 2007, http://www.biogeosciences.net/4/837/2007/.

Guidi, L., Gorsky, G., Claustre, H., Picheral, M., and Stemmann, L.: Contrasting distribution of aggregates $>100 \mu \mathrm{m}$ in the upper kilometre of the South-Eastern Pacific, Biogeosciences Discuss., 5, 871-901, 2008, http://www.biogeosciences-discuss.net/5/871/2008/.

Hardy, J., Hanneman, A., Behrenfeld, M., and Horner, R.: Environmental hiogeography of near-surface phytoplankton in the southeast Pacific Ocean, Deep Sea Res. Part I, 43, 1647-1-659, 1996.

Huot, Y., Babin, M., Bruyant, F., Grob, C., Twardowski, M. S., and Claustre, H.: Does chlorophyll- $a$ provide the best index of phytoplankton biomass for primary productivity studies?, Biogeosciences, 4, 853-868, 2007, http://www.biogeosciences.net/4/853/2007/.

Huot, Y., Morel, A., Twardowski, M. S., Stramski, D., and Reynolds, R. A.: Particle optical backscattering along a chlorophyll gradient in the upper layer of the eastern South Pacific Ocean, Biogeosciences, 5, 495-507, 2008,

http://www.biogeosciences.net/5/495/2008/.

Kessler, W. S.: The circulation of the Eastern Tropical Pacific: A review, Progress In Oceanography, 69, 181, 2006.

Le Gall, F., Rigaut-Jalabert, F., Marie, D., Garczarek, L., Viprey, M., Gobet, A., and Vaulot, D.: Picoplankton diversity in the South-East Pacific Ocean from cultures, Biogeosciences, 5, 203 214, 2008, http://www.biogeosciences.net/5/203/2008/.

Leth, O. and Shaffer, G.: A numerical study of the seasonal variability in the circulation off central chile, J. Geophys. Res., 106, 22 229-22 248, 2001.

Leth, O., Shaffer, G., and Ulloa, O.: Hydrography of the eastern South Pacific Ocean: Results from the sonne 102 cruise, mayjune 1995, Deep-Sea Res. II, 51, 2349-2369, 2004.

Loisel, H., Nicolas, J. M., Sciandra, A., Stramski, D., and Poteau, A.: Spectral dependency of optical backscattering by marine particles from satellite remote sensing of the global ocean, J. Geophys. Res., 111, C09024, doi:10.1029/2005JC003367, 2006.

Longhurst, A.: Ecological geography of the sea, Academic Press, 398 pp., 1998.

Mahowald, N. M., Baker, A. R., Bergametti, G., Brooks, N., Duce, R. A., Jickells, T. D., Kubilay, N., Prospero, J. M., and Tegen, I.: Atmospheric global dust cycle and iron inputs to the ocean, Glob. Biogeochem. Cy., 19, GB4025, doi:10.1029/2004GB002402, 2005.

Martin, J. H., Coale, K. H., Johnsson, K. S., et al.,: Testing the iron hypothesis in ecosystems of the equatorial Pacific Ocean, Nature, 371, 123-129, 1994.

Martinez, E. and Maamaatuaiahutapu, K.: Island mass effect in the marquesas islands: Time variation, Geophys. Res. Lett., 31, L18307, doi:10.1029/2004GL020682, 2004.

Masquelier, S. and Vaulot, D.: Distribution of micro-organisms along a transect in the South-East Pacific Ocean (BIOSOPE cruise) from epifluorescence microscopy, Biogeosciences, 5, 311-321, 2008, 
http://www.biogeosciences.net/5/311/2008/.

Messié, M., Radenac, M.-H., Lefèvre, J., and Marchesiello, P.: Chlorophyll bloom in the western pacific at the end of the 19971998 el niño: The role of the Kiribati Islands., Geophys. Res. Lett., 33, L14601, doi:10.1029/2006GL026033, 2006.

Morel, A., Claustre, H., Antoine, D., and Gentili, B.: Natural variability of bio-optical properties in case 1 waters: Attenuation and reflectance within the visible and near-uv spectral domains, as observed in South pacific and mediterranean waters, Biogeosciences, 4, 913-925, 2007a,

http://www.biogeosciences.net/4/913/2007/.

Morel, A., Gentili, B., Claustre, H., Babin, M., Bricaud, A., Ras, J., and Tieche, F.: Optical properties of the "clearest" natural waters, Limnol. Oceanogr., 52, 217-229, 2007b.

Moutin, T., Karl, D. M., Duhamel, S., Rimmelin, P., Raimbault, P., Van Mooy, B. A. S., and Claustre, H.: Phosphate availability and ultimate control of new nitrogen input by nitrogen fixation in the tropical Pacific Ocean., Biogeosciences, 5, 95-109, 2008, http://www.biogeosciences.net/5/95/2008/.

Murray, J. W., Barber, R. T., Roman, M. R., Bacon, M. P., and Feely, R. A.: Physical and biological controls on carbon cycling in the Equatorial Pacific, Science, 266, 58-65, 1994.

Murray, J. W., Johnson, E., and Garside, C.: A U.S. JGOFS process study in the equatorial pacific (eqpac): Introduction, Deep Sea Res. Part II, 42, 275, 1995.

Murray, J. W., Leborgne, R., and Dandonneau, Y.: JGOFS studies in the Equatorial Pacific (EQPAC), Deep Sea Res. Part II, 44, 1759, 1997.

Obernosterer, I., Catala, P., Lami, R., Caparros, J., Ras, J., Bricaud, A., Dupuy, C., Van Wambeke, F., and Lebaron, P.: Biochemical characteristics and bacterial community structure of the sea surface microlayer in the South Pacific Ocean, Biogeosciences Discuss., 4, 2809-2844, 2007,

http://www.biogeosciences-discuss.net/4/2809/2007/.

Raimbault, P., and Garcia, N.: Evidence for efficient regenerated production and dinitrogen fixation in nitrogen-deficient waters of the South Pacific Ocean: impact on new and export production estimates, Biogeosciences, 5, 323-338, 2008, http://www.biogeosciences.net/5/323/2008/.

Raimbault, P., Garcia, N., and Cerrutti, F.: Distribution of inorganic and organic nutrients in the South Pacific Ocean -evidence for long-term accumulation of organic matter in nitrogen-depleted waters, Biogeosciences, 5, 281-298, 2008,

http://www.biogeosciences.net/5/281/2008/.

Ras, J., Uitz, J., and Claustre, H.: Spatial variability of phytoplankton pigment distribution in the South East Pacific, Biogeosciences, 5, 353-369, 2008,

http://www.biogeosciences.net/5/353/2008/.

Reid, J. L.: Transpacific hydrographic sections at lats. $43^{\circ} \mathrm{S}$ and $28^{\circ} \mathrm{S}$ : The scorpio expedition-iii. Upper water and a note on southward flow at mid-depth, Deep-Sea Res., 20, 39-49, 1973.

Schneider, W., Fuenzalida, R., RodrÍguez-Rubio, E., GarcésVargas, J., and Bravo, L.: Characteristics and formation of eastern south pacific intermediate water, Geophysical Research Letters, 30(11), 1581, doi:1510.1029/2003GL017086, 2003.

Sempéré, R., Tedetti, M., Panagiotopoulos, C., Charrière, B., and Van Wambeke, F.: Molecular distribution and bacterial availability of dissolved sugars in the South East Pacific Ocean in relation to photochemical oxidation reactions, Biogeosciences Discuss.,
725-750, 2008.

Shaffer, G., Salinas, S., Pizarro, O., Vega, A., and Hormazabal, S.: Currents in the deep ocean off Chile ( $\left.30^{\circ} \mathrm{S}\right)$, Deep-Sea Res., 42, 425-436, 1995.

Siegel, D. A., Maritorena, S., Nelson, N. B., Hansell, D. A., and Lorenzi-Kayser, M.: Global distribution and dynamics of colored dissolved and detrital organic materials, J. Geophys. Res., 107, 3228, doi:3210.1029/2011JC000965, 2002.

Signorini, S. R., McClain, C. R., and Dandonneau, Y.: Mixing and phytoplankton bloom in the wake of the Marquesas islands, Geophys. Res. Lett., 26, 3121-3124, 1999.

Silva, N. and Neshyba, S.: On the southernmost extension of the Peru-Chile undercurrent, Deep-Sea Res., 26, 1387-1393, 1979.

Stemmann, L., Eloire, D., Sciandra, A., Jackson, G. A., Guidi, L., Picheral, M., and Gorsky, G.: Volume distribution for particles between 3.5 to $2000 \mu \mathrm{m}$ in the upper $200 \mathrm{~m}$ region of the South Pacific Gyre, Biogeosciences, 5, 299-310, 2008, http://www.biogeosciences.net/5/299/2008/.

Stramma, L., Peterson, R. G., and Tomczak, M.: The South Pacific current, Journal of Physical Oceanography, 25, 77-91, 1995.

Stramski, D., Reynolds, R. A., Babin, M., Kaczmarek, S., Lewis, M. R., Rottgers, R., Sciandra, A., Stramska, M., Twardowski, M. S., Franz, B. A., and Claustre, H.: Relationships between the surface concentration of particulate organic carbon and optical properties in the eastern South Pacific and eastern Atlantic oceans, Biogeosciences, 5, 171-201, 2008, http://www.biogeosciences.net/5/171/2008/.

Tédetti, M., Sempere, R., Vasilkov, A., Charriere, B., Nerini, D., Miller, W. L., Kawamura, K., and Raimbault, P.: High penetration of ultraviolet radiation in the South East Pacific waters, Geophys. Res. Lett., 34, L12610, doi:12610.11029/12007GL029823, 2007.

Thomas, A. C., Huang, F., Strub, P. T., and James, C.: A comparison of the seasonal and interannual variability of phytoplankton pigment concentrations in the Peru and California current systems, J. Geophys. Res., 99, 7355-7370, 1994.

Tolosa, I., Miquel, J. C., Gasser, B., Raimbault, P., Azousi, L., and Claustre, H.: Ecology and biogeochemistry of contrasting trophic environments in the South East Pacific by carbon isotope ratios on lipid biomarkers., Biogeosciences Discussion, 4, 46534696, 2007.

Tomczak, M. and Godfrey, J. S.: Regional oceanography: An introduction., Pdf Version 1.2, available from: http://www.es.flinders. edu.au/ mattom/regoc/, 2001.

Tsuchiya, M. and Talley, L. D.: A Pacific, 88० hydrographic section at $88^{\circ}$ w: Water-property distribution, J. Geophys. Res., 103 , 12 899-12 918, 1998.

Twardowski, M. S., Claustre, H., Freeman, S. A., Stramski, D., and Huot, Y.: Optical backscattering properties of the "clearest" natural waters, Biogeosciences, 4, 1041-1058, 2007, http://www.biogeosciences.net/4/1041/2007/.

Uitz, J., Claustre, H., Morel, A., and Hooker, S.: Vertical distribution of phytoplankton communities in open ocean: An assessment based on surface chlorophyll, J. Geophys. Res., 111, C08005, doi:10.1029/2005JC003207, 2006.

Uitz, J., Huot, Y., Bruyant, F., Babin, M., and Claustre, H.: Relating phytoplankton photophysiological properties to community structure on large scale, Limnol. Oceanogr., 53, 614-630, 2008.

Van Mooy, B. A. S., Moutin, T., Duhamel, S., Rimmelin, P., and 
Van Wambeke, F.: Phospholipid synthesis rates in the eastern subtropical South Pacific Ocean, Biogeosciences, 5, 133-139, 2008 ,

http://www.biogeosciences.net/5/133/2008/.

Van Wambeke, F., Bonnet, S., Moutin, T., Raimbault, P., Alarçon, G., and Guieu, C.: Factors limiting heterotrophic prokaryotic production in the southern Pacific Ocean, Biogeosciences Discuss., 4, 3799-3828, 2007a,

http://www.biogeosciences-discuss.net/4/3799/2007/.

Van Wambeke, F., Obernosterer, I., Moutin, T., Duhamel, S., Ulloa, O., and Claustre, H.: Heterotrophic bacterial production in the South East Pacific: Longitudinal trends and coupling with primary production, Biogeosciences, 5, 157-169, 2008, http://www.biogeosciences.net/5/157/2008/.

Van Wambeke, F., Tedetti, M., Duhamel, S., and Sempéré, R.: Diel variability of heterotrophic prokaryotic production and UV doses in the South East Pacific, Biogeosciences Discuss., 5, 435-462, $2007 b$, http://www.biogeosciences-discuss.net/5/435/2007/.

Vasilkov, A. P., Krotkov, N., Herman, J., McClain, C., Arrigo, K. R., and Robinson, W.: Global mapping of underwater uv irradiances and DNA-weighted exposures using total ozone mapping spectrometer and sea-viewing wide filed-of-view sensor data products, J. Geophys. Res., 106, 27 205-27 219, 2001.
Voss, K. J., Morel, A., and Antoine, D.: Detailed validation of the bidirectional effect in various case 1 waters for application to ocean color imagery, Biogeosciences, 4, 781-789, 2007, http://www.biogeosciences.net/4/781/2007/.

Wagener, T., Guieu, C., Losno, R., Bonnet, S., and Mahowald, N.: Revisiting atmospheric dust export to the south hemisphere ocean, Glob. Biogeochem. Cy., 22, GB2006, doi:10.1029/2007GB002984, 2008.

Wang, L., Koblinsky, C. J., Howden, S. D., and Beckley, B.: Largescale rossby wave in the mid-latitude south pacific from altimetric data, Geophys. Res. Lett., 25, 179-182, 1998.

Wijffels, S. E., Toole, J. M., and Davis, R.: Revisiting the south pacific subtropical circulation: A synthesis of world ocean circulation experiment observations along $32^{\circ} \mathrm{S}$, J. Geophys. Res., 106, 19481-19513, 2001.

Wyrtki, K., and Kilonsky, B.: Mean water and current structure during the hawaii-to-tahiti shuttle experiment, Journal of Physical Oceanography, 14, 242-254, 1984.

Yoder, J. A. and Kennelly, M. A.: Seasonal and enso variability in global ocean: Phytoplankton chlorophyll derived from four years of seawifs measurements, Glob. Biogeochem. Cy., 17, 1112, doi:1110.1029/2002GB001942, 2003.

Yuras, G., Ulloa, O. and Hormazábal, S.: On the annual cycle of coastal and open ocean satellite chlorophyll off Chile $\left(18^{\circ}-\right.$ $\left.40^{\circ} \mathrm{S}\right)$. Geophys. Res. Lett., 32, 1029-1033, 2005. 